\title{
The Amundsen Sea Low
}

John Turner, Tony Phillips, J. Scott Hosking, Gareth J. Marshall and Andrew Orr

British Antarctic Survey, Natural Environment Research Council, High Cross, Madingley Road, Cambridge, CB3 OET

Corresponding author address. J Turner, British Antarctic Survey, Natural Environment Research Council, High Cross, Madingley Road, Cambridge, CB3 0ET.

Tel (01223) 221485, Fax (01223) 221279, Email JTU@BAS.AC.UK

Short Title - The Amundsen Sea Low

Keywords - Antarctica, depressions, Antarctic Peninsula, West Antarctica

\begin{abstract}
We develop a climatology of the Amundsen Sea Low (ASL) covering the period 1979-2008 using ECMWF operational and reanalysis fields. The depth of the ASL is strongly influenced by the phase of the Southern Annular Mode (SAM) with positive (negative) MSLP anomalies when the SAM is negative (positive). The zonal location of the ASL is linked to the phase of the mid-tropospheric planetary waves and the low moves west from close to $110^{\circ} \mathrm{W}$ in January to near $150^{\circ} \mathrm{W}$ in June as planetary waves 1 to 3 amplify and their phases shift westwards. The ASL is deeper by a small, but significant amount, during the La Niña phase of ENSO compared to El Niño. The difference in depth of the low between the two states of ENSO is greatest in winter. There is no statistically significant difference in the zonal location of the ASL between the different phases of ENSO. Over 1979-2008 the low has deepened in January by $1.7 \mathrm{hPa}^{-1} \mathrm{dec}^{-1}$ as the SAM has become more positive. It has also deepened in spring and autumn as the semi-annual oscillation has increase in amplitude over the last 30 years. An increase in central pressure and eastward shift in March has occurred as a result of a cooling of tropical Pacific SSTs that altered the strength of the polar front jet.
\end{abstract}




\section{Introduction}

The mean sea level pressure (MSLP) field around high southern latitudes is dominated by the circumpolar trough across $60-70^{\circ} \mathrm{S}$. Within this there are three climatological low pressure centres located close to $20^{\circ} \mathrm{E}, 90^{\circ} \mathrm{E}$ and $150^{\circ} \mathrm{W}$ (Figure 1), which are associated with the strong wave number 3 circulation around the Antarctic (Raphael, 2004). The three low centres are found throughout the depth of the troposphere, since the circulation in the Antarctic coastal region is essentially equivalent barotropic. The location and depth of the three surface lows has a strong influence on the climatic conditions in the Antarctic coastal region.

The climatological low pressure centre in the area of the Amundsen/Ross Seas is generally known as the Amundsen Sea Low (ASL) (Baines and Fraedrich, 1989; Bertler et al., 2004; Kreutz et al., 2000a), although it has recently been referred to as the AmundsenBellingshausen Seas Low (Fogt et al., 2012). The depth and location of this centre off the coast of West Antarctica affects the broadscale climatic conditions between the Antarctic Peninsula and the Ross Ice Shelf, and the interior of West Antarctic, which is a region of marked change in recent decades (Ding et al., 2011; Schneider et al., 2012). This area close to $150^{\circ} \mathrm{W}$ is at the boundary of the Amundsen and Ross Seas, however, we will follow the convention established in earlier papers and refer to this climatological low pressure system as the ASL.

The reason for the climatological wave number 3 pattern in the Antarctic atmospheric circulation was investigated by Baines and Fraedrich (1989) via tank experiments. They showed that this feature was a result of flow separation around coastal irregularities, with the ASL being present because of strong flow around the northward extension of the orography near $150^{\circ} \mathrm{E}$ and the presence of the Ross Sea embayment.

To the east of the ASL there is a north to northwesterly flow that is responsible for the relatively mild conditions that are experienced on the western side of the Antarctic Peninsula. To the west of the Antarctic Peninsula, the coast of Ellsworth Land is north-facing and the prevailing northerly flow is responsible for the area having some of the largest totals of snow accumulation in the Antarctic (Vaughan et al., 1999). To the west of the ASL there is a southerly flow that contributes to the forcing of the flow off the Ross Ice Shelf, which in turn enhances the extensive sea ice production in this area (Tamura et al., 2008).

The atmospheric circulation variability over the Amundsen-Bellingshausen Sea (ABS) is larger than in any other region of the Southern Hemisphere (Lachlan-Cope et al., 
2001). This can be seen via the large variability of the MSLP and upper air height fields, as well as in quantities such as cyclone density. Experiments with a general circulation model showed that this region of high variability was present because of the shape of the Antarctic ice sheet and the location of the highest orography some distance from the South Pole (Lachlan-Cope et al., 2001).

Variability in the depth and location of the ASL has a profound effect on the climate of the Antarctic Peninsula and the ocean areas to the west. Changes in the ASL affect the strength of the north to northwesterly flow down the Peninsula, which in turn affects the amount and meridional extent of sea ice. Years of weak (strong) northerly flow are characteristed by extensive (little) sea ice extent and few (many) precipitation reports at the stations on the western side of the Peninsula (Turner et al., 1997). There is also a high anticorrelation between the extent of sea ice over the ABS and winter season temperatures on the western side of the Peninsula. Since the 1950s, winter surface air temperatures at Faraday/Vernadsky station have increased as much as anywhere in the Southern Hemisphere (Turner et al., 2005); a change that suggests that there might have been more extensive sea ice in the middle of the Twentieth Century and possibly a weaker ASL (King and Harangozo, 1998).

Variability in the depth and location of the ASL has been linked to several aspects of the Antarctic climate, as well as tropical conditions. Cullather (1996) suggested that over the period 1980-1990 the ASL shifted 1,400 km further east during El Niño conditions compared to the climatological location. A deepening of the ASL has also been reported during El Niño events (Kreutz et al., 2000b). Bertler et al. (2004) constructed conceptual models of the low level flow in the Amundsen Sea area during El Niño and La Niña events and related the movement of the ASL to intrusions of cold, continental air down from West Antarctic onto the Ross Ice Shelf and along the Transantarctic Mountains to the McMurdo Dry Valley. The relationship of the depth and location of the ASL to the El Niño-Southern Oscillation (ENSO) was summarized as a deepening (weakening) and westward (eastward) movement of the low during La Niña (El Niño) events, results that are the reverse of those found by Kreutz et al. (2000a). They also attributed the recent cooling in the Dry Valleys (Doran et al., 2002) to a shift of the ENSO in recent decades towards more frequent and deeper El Niño events, with subsequent changes to the atmospheric flow in the Amundsen Sea region .

There has been a great deal of research into the relationship between ENSO and Antarctica (for a review see Turner, 2004) and analyses have suggested that there are indeed strong influences of tropical conditions on the atmospheric, oceanic and cryospheric 
conditions in the Antarctic (Yuan and Martinson, 2001). However, the extra-tropical response of some ENSO events at high southern latitudes can be variabile and some studies have questioned the extent to which we can expect a linear relationship between indices of ENSO, such as the Southern Oscillation Index (SOI), and the conditions around the Antarctic (Lachlan-Cope and Connolley, 2006).

The primary mode of atmospheric variability at high southern latitudes is the Southern Annular Mode (SAM) (Limpasuvan and Hartmann, 1999). Variability in the SAM has been shown to have a profound impact on many aspects of the atmospheric (Genthon et al., 2003; Marshall et al., 2006; Schneider et al., 2004; Thompson and Solomon, 2002) and oceanic (Hall and Visbeck, 2002; Le Quére et al., 2009) conditions of the Antarctic and Southern Ocean. There are also indications that the relative phases of ENSO and the SAM have an impact on the atmospheric circulation of high southern latitudes (Fogt et al., 2011; Fogt and Bromwich, 2006).

The series of reliable atmospheric analyses that we have available to investigate variability and change in the ASL is relatively short. The reanalysis projects have produced sequences of surface and upper air fields that in some cases start in the 1950s. However, it is generally accepted that at high southern latitudes they have limited value for change studies prior to 1979 as a result of the lack of satellite sounder data for use in the analysis process (Hines et al., 2000).

In this paper we create a climatology of the ASL covering the period since 1979 and examine the variability and change in the low over the period. Section 2 describes the various forms of data used and the derivation of the climatology of the ASL. The climatological characteristics and variability of the ASL are examined in Section 3, with the relationship to the major modes of climate variability considered in Section 4. Section 5 documents changes in the low over the last 30 years. We draw conclusions in Section 6 and consider future worked needed.

\section{Data and methods}

\subsection{Data}

This study is based on the 6 hourly ECMWF 40 year re-analysis (ERA-40) fields (Uppala et al., 2005) for the period 1979-2001 and the ECMWF operational analyses for 2002-2008. The ERA fields have a horizontal resolution of approximately $125 \mathrm{~km}$ and the operational 
fields are reduced to this resolution. Although there are relatively few in-situ meteorological measurements available from the sector of the Antarctic from the Peninsula to the Ross Sea, there are a large number of satellite sounding observations and other remote sensing data, allowing the production of analyses that are reasonably accurate. King (2003) assessed the accuracy of ECMWF operational analyses against MSLP observations from drifting buoys in the Bellingshausen Sea, which critically had not been included in the ECMWF operational analysis procedure and so provided an independent form of verification data. He found that the standard deviations of the differences between the buoy observations and the analysed MSLP were typically around $1 \mathrm{hPa}$.

In this study we have used MSLP fields from both the ERA-40 exercise and the operational analysis system, since the ERA-40 data set finishes in February 2002. It is instructive to examine how these two sets of analyses differ in the overlap period. Figure 2 therefore shows the monthly mean MSLP from ERA-40 for the area $60-75^{\circ} \mathrm{S}, 50-180^{\circ} \mathrm{W}$ (our ASL analysis area discussed below) for the period January 2000 to February 2002 and the difference between the two analyses. The mean difference for the period was $0.027 \mathrm{hPa}$ and the standard deviation $0.37 \mathrm{hPa}$, with maximum differences of $0.7 \mathrm{hPa}$ (October 2001) and $-0.7 \mathrm{hPa}$ (February 2002). Such small differences between the analyses mean that it is very unlikely that there will be any jump in our ASL climatology at the transition between the two data sets.

To examine the relationship between the depth and location of the ASL and regional and global climatic conditions we have used several data sets and indices. Global sea surface temperatures were obtained from the UK Hadley Centre Sea Ice and Sea Surface Temperature (HadISST) data set (http://www.metoffice.gov.uk/hadobs/hadisst/)/. The phase of the ENSO was determined using the Nino 3.4 region monthly mean temperatures from the NOAA Climate Prediction Center http://www.cpc.ncep.noaa.gov/data/indices/. The phase of the SAM was obtained from the SAM index created by Gareth Marshall at the British Antarctic Survey (http://www.nerc-bas.ac.uk/icd/gjma/sam.html).

\subsection{The ASL climatology}

The climatology of the ASL was created from the monthly mean MSLP fields produced by the ECMWF reanalysis and operational data assimilation schemes. The location of the ASL for each month was determined by searching for the grid point with the lowest MSLP within the latitude/longitude box bounded by $50^{\circ} \mathrm{W}, 180^{\circ} \mathrm{W}, 60^{\circ} \mathrm{S}$ and $75^{\circ} \mathrm{S}$. The 
ASL study of Fogt et al. (2012) considered MSLP across a larger area, but as with any low pressure system, taking the central location and depth provides clear metrics that can be investigated and related to other climatological variables. Examination of the mean MSLP charts indicates that during the vast majority of months there is a clearly defined ASL. In a very small number of months there was a suggestion of two low pressure centres in the South Pacific sector of the Antarctic coastal region, but one always had a significantly lower MSLP than the other and this was taken as the location of the ASL.

The ASL climatology therefore consists of a location and depth of the low for each month over the period 1979-2008. This was related to global and regional synoptic fields and changes in the modes of climate variability.

\subsection{The atmospheric planetary waves}

Earlier research has suggested that variability and change in the amplitude and phase of the tropospheric planetary waves is important in affecting the broadscale circulation of high southern latitudes (Hobbs and Raphael, 2007). We have therefore investigated the relationship between the planetary waves and the ASL. The amplitudes and phases of waves 1 to 10 were examined by carrying out a Fourier analysis of the monthly mean $500 \mathrm{hPa}$ geopotential heights around $65^{\circ} \mathrm{S}$. In later sections the changes in the nature of the planetary waves, and particularly wave numbers 1 to 3 , are related to the location and depth of the ASL.

\section{Climatological characteristics of the ASL}

The ASL exhibits changes in depth and location over the year. The depth of the low (Figure 3) shows a semi-annual oscillation with minima (maxima) of MSLP in the autumn and spring (summer and winter). This form of annual pressure cycle is similar to that at coastal stations on the Antarctic Peninsula and the Ross Ice Shelf and is present because of the southerly (northerly) movement and deepening (filling) of the depressions in the circumpolar trough over the year. Over the period $1979-2008$ the mean surface pressure of the ASL was lowest during October $(970.5 \mathrm{hPa})$ and highest during January (981.2 $\mathrm{hPa})$. Conversely, the zonal and meridional positions of the ASL are dominated by an annual cycle with the low being further west (east) and south (north) in winter (summer) (Figure 4). This westward migration of the ASL from its mean position close to $110^{\circ} \mathrm{W}$ to $153^{\circ} \mathrm{W}$ takes 
place between January and June, with the low moving back to $120^{\circ} \mathrm{W}$ by December. There is a suggestion within the zonal position data of the SAO as the east-west movement slows between March and April, and August and October. Basic synoptic meteorology tells us that a surface low is often associated with an upper level trough, with the surface low often being slightly to the east of the upper level feature. So it is not surprising that there is a strong correlation between the zonal position of the ASL and the longitude of the $500 \mathrm{hPa}$ trough in this sector of the Antarctic. The mid-tropospheric circulation of high southern latitudes has a strong wave number 3 pattern and examination of changes in the nature of this wave over the year are of value in understanding the changes in the ASL. Figure 5 shows the mean annual cycle of the amplitude and phase of this wave at $65^{\circ} \mathrm{S}$ for the period 1979-2008. The data indicate that between summer and winter the amplitude of the wave increases from 25 to $48 \mathrm{~m}$ and that there is a westward shift in the phase of about 30 degrees. In June the sd of the longitude of the ASL is at a minimum for the year at $22^{\circ}$ of longitude, reflecting the strong wave 3 pattern in this sector and the limited inter-annual variability. The changes over the year can be appreciated from the mean $500 \mathrm{hPa}$ height fields for January and June shown in Figure 6. In January the wave 3 pattern is apparent with weak troughs close to $0^{\circ} \mathrm{E}, 120^{\circ} \mathrm{E}$ and $100^{\circ} \mathrm{W}$. But in June (Figure $6 \mathrm{~b}$ ) the amplitude of the wave 3 pattern is much more pronounced and with the troughs located close to $30^{\circ} \mathrm{W}, 90^{\circ} \mathrm{E}$ and $150^{\circ} \mathrm{W}$. The work of Baines and Fraedrich suggested that the wave number 3 form of the MSLP field around the Antarctic was present because of the strong westerly flow around the continent and the shape of the orography. The annual cycle in the development of the wave number 3 suggests that it is associated with the development of the polar vortex and the increase in mid to upper tropospheric wind speeds around the continent. Wave numbers 1 and 2 also increase in amplitude between the summer and winter, however, wave number 4 , which has a much smaller amplitude than the longer waves, has a semi-annual form in its amplitude over the year.

The interannual variability in the longitude of the ASL is significantly correlated with the zonal and meridional wind speeds around the Antarctic continent. Figure 7 shows the correlations in winter of the longitude of the low with these two components of the flow at the $500 \mathrm{hPa}$ level. It can be seen that stronger westerly flow over the Southern Ocean between the Ross Sea and the South Atlantic results in a more easterly location for the ASL. Figure $7 \mathrm{~b}$ indicates that the zonal position of the planetary waves in the South Pacific sector of the South Ocean also affected the zonal location of the ASL, although this is not surprising as there is such a high degree of coupling between surface lows and the mid-tropospheric 
planetary waves.

The climatology of the wave number 3 phase shows that there is a relatively large variability in the phase of the wave, with the standard deviation in winter being $16^{\circ}$. However, the zonal location of the ASL is also affected by local factors as well the hemisphere-wide wave number 3 index. And examining the long-term relationship between the zonal location of the ASL and the phase of wave number 3 shows that the connection varies with time. For example, between 1979 and 1994 the two quantities followed each other quite closely and the correlation was 0.88 . However, for $1994-2008$ the correlation dropped to 0.10 as the ASL was much more westward and located between 140 and $160^{\circ} \mathrm{W}$, and did not have the eastward locations found in the earlier part of the record.

The mean latitude of the ASL also exhibits an annual cycle moving south between summer and winter, although its most southerly location is in August rather than June when it reaches its most westerly location. The southward movement takes place as the main polar front jet moves south from close to $51^{\circ} \mathrm{S}$ in January to $61^{\circ} \mathrm{S}$ in August, based on the mean $300 \mathrm{hPa}$ zonal wind speed across $70-180^{\circ} \mathrm{W}$. The polar front jet is well north of the ASL, but over the first half of the year the ASL moves south as the belt of strong winds south of the jet move into the Antarctic coastal zone.

The annual cycle of MSLP between $70^{\circ}$ and $180^{\circ} \mathrm{W}$ and averaged over $66.7^{\circ}$ and $72.3^{\circ} \mathrm{S}$ is shown in Figure 8. This presents another view of how the pressure field evolves over the year and its relationship to the ASL. The dominant signal is the SAO, which is apparent as lower (higher) pressures during the spring and autumn (winter and summer). Figure 8 presents the mean MSLP over $66.7-72.3^{\circ} \mathrm{S}$ and the ASL depth/location is not directly comparable to the data from the climatology of the low. However, it does provide some insight into the relationship of the ASL with the broad scale pressure field. It shows two clear centres of low pressure close to $150^{\circ} \mathrm{W}$ in April and October that correspond to the general location of the ASL. In June, when the ASL is at its most westerly location, Figure 8 shows that MSLP is relatively high between 70 and about $120^{\circ} \mathrm{W}$ and that the ASL is located in a weak col of low pressure near $160^{\circ} \mathrm{W}$. During December/January there is also a weak pressure gradient across the area and the ASL is located in the weak trough area near $100^{\circ} \mathrm{W}$.

The inter-annual variability in the depth of the ASL has a maximum in June at $6.7 \mathrm{hPa}$ and secondary peaks in February and September (Figure 3) Over the 30 year period of the study the winter season central pressure of the ASL varied from 967 to $990 \mathrm{hPa}$. The correlations of the winter and summer depths of the low with the $500 \mathrm{hPa}$ heights across the high latitude areas of the Southern Hemisphere during these seasons are shown in Figure 9. 
Not surprisingly, the highest correlations are above the surface low since the atmosphere is essentially equivalent barotropic. However, the pattern of correlation across the rest of high southern latitudes varies throughout the year. During summer the field of correlation has positive (negative) values over high latitudes (mid-latitudes), a pattern that strongly resembles the MSLP and height changes associated with different phases of the SAM. The links between the ASL and the SAM will be discussed in Section 4. In the other three seasons (Figure 9 only illustrates the Summer and Winter seasons) there is still a positive correlation between the depth of the ASL and geopotential heights over the whole continent, but the ring of negative correlations becomes fragmented and in spring has three clear centres, suggesting a link with the phase and amplitude of wave number 3. A greater amplitude of the wave number 3 during spring is associated with a slightly deeper ASL, although the anticorrelation is weak at -0.28 . In all seasons except summer there is a sequence of statistically significant negative/positive/negative correlations extending from New Zealand to the tip of South America suggesting the involvement of forcing from lower latitudes. The pattern of correlation has some similarities to the low-high latitude Pacific South American (PSA) teleconnection and will be discussed in Section 4.

The MSLP values in the circumpolar trough are strongly dependent on the phase of the SAM, so the absolute depth of the ASL will be influenced by this zonal circulation index, although local factors will also play a part. Figure 10 shows the depth of the ASL and the SAM index during autumn. These two quantities have a correlation of -0.65 , with periods when the SAM is in the positive phase resulting in a deeper ASL.

The zonal location of the ASL is affected by the positions of the planetary waves so it is instructive to examine the correlation of the longitude of the low and the $500 \mathrm{hPa}$ geopotential height field. The pattern of correlation is similar in all seasons so here we present the data for Winter, which are shown in Figure 11. This has a strong wave 3 form with significant areas of positive correlation close to $90^{\circ} \mathrm{E}$ and $20^{\circ} \mathrm{W}$, and a couplet of positive/negative correlation peaks between the Antarctic Peninsula and the Ross Sea. In other seasons the magnitudes of the correlation values are smaller than in winter reflecting the broader mid-tropospheric trough that is present.

The magnitude of the variability in the latitude of the ASL exhibits a semi-annual oscillation with minima (maxima) in late winter/spring and autumn (summer and winter) (see Figure $4 \mathrm{~b}$ ). The cycle in the variability has this form since the strength of the polar front jet is greater and has less variability during the autumn and spring seasons. 


\section{Links between the ASL and the large-scale modes of climate variability}

Atmospheric conditions in the area between the Antarctic Peninsula and the Ross Sea are affected strongly by changes in the state of the SAM and ENSO. As discussed in Section 3, variability in the SAM affects the MSLP over the Antarctic continent and mid-latitudes, and influences the depth and location of the ASL. Overall the MSLP is lower in the circumpolar trough, including in the region of the ASL, when the SAM is in its positive phase (Figure 10). The ABS is the region of the Southern Ocean where there are the most direct atmospheric links between the climate of the tropical Pacific and the high latitude regional climate, with the PSA pattern giving higher (lower) MSLP during El Niño (La Niña) events (Lachlan-Cope and Connolley, 2006; Turner, 2004; Yuan, 2004). The signals of the PSA and the SAM interact in the region of the ASL so that MSLP pressure is lower (higher) during the La Nina phase/positive SAM (El Nino/negative SAM) (Fogt et al., 2011). In this section we examine the variability in the depth and location of the ASL in relation to tropical SSTs and the phase of the SAM.

Stammerjohn et al. (2008) split the conditions in the Antarctic coastal region into the four permutations generated from El Niño, La Niña, SAM positive and SAM negative. However, even for the year as a whole there are only six individual months when the SAM was negative during La Niña conditions and in the winter, spring and autumn seasons there is only one month in each when the conditions are La Niña and SAM negative. We will therefore focus on examining separately the changes in the ASL at different phases of the ENSO and SAM cycles.

We use the 5 month running mean of the SST in the Nino 3.4 region to identify El Niño and La Niña events. We've taken months to be in the El Niño (La Niña) phase if the running mean SST anomaly was greater (less) than $0.5^{\circ} \mathrm{C}\left(-0.5^{\circ} \mathrm{C}\right)$. Using these definitions there were 94 El Niño and 79 La Niña months.

For the data covering 1979 - 2008 we removed the monthly mean MSLP from the depth of the low since the SAO modulates the MSLP by several hPa over the course of the year. We then computed the mean MSLP for the central pressure of the ASL for months when the SAM index was greater than +1 and less than -1 . For the year as a whole the ASL central MSLP anomalies were $3.43 \mathrm{hPa} \pm 10.5 \mathrm{hPa}$ when the SAM was negative ( 85 months) and $-2.87 \mathrm{hPa} \pm 8.7 \mathrm{hPa}$ when the SAM was positive (124 months). Although the variability of the MSLP is large during both phases of the SAM the two populations of ASL depth are statistically significantly different at $<1 \%$ level based on a t test. 
To investigate the variability of the depth of the ASL with the ENSO cycle we have again used the monthly MSLP anomalies so as to remove the signal of the SAO cycle. For 1979 - 2008 the mean MSLP anomalies for months in the El Nino (La Nina) phase were $+0.83 \mathrm{hPa} \pm 9.94 \mathrm{hPa}(-2.55 \mathrm{hPa} \pm 9.40 \mathrm{hPa})$. Again, despite the large variability of the MSLP values the differences in the values during El Nino and La Nina months are statistically significantly different at $<1 \%$ level based on a t test. The higher pressures at the centre of the ASL during El Niño events is consistent with the greater amount of blocking to the west of the Antarctic Peninsula noted in earlier studies (e.g. Karoly, 1989). In addition, a deeper ASL during La Niña periods has been noted in the studies of Yuan (2004) and Stammerjohn et al. (2008). However, the difference in depth of the low between the two states of ENSO varies over the year from a minimum of $0.36 \mathrm{hPa}$ in Autumn to a maximum of $3.7 \mathrm{hPa}$ in Winter, with the low always being deeper during La Niña conditions.

The meridional location of the ASL is most strongly influenced by the phase of the $\mathrm{SAM}$, with its mean position for the year as a whole being $68.72^{\circ} \mathrm{S} \pm 6.76^{\circ}$ for negative conditions and $70.43^{\circ} \mathrm{S} \pm 6.10^{\circ}$ for the positive phase (statistically significantly different at the $1 \%$ level). This is consistent with the overall southward movement of the main storm tracks when the SAM is positive. The change is smaller between stages of the ENSO cycle, with the comparable figures being $70.19^{\circ} \mathrm{S}$ for El Niño months and $69.28^{\circ} \mathrm{S}$ for La Niña, which is not statistically different.

Changes in the phase of the SAM have little impact on the zonal location of the ASL with the annual mean longitude of the low being $128.76^{\circ} \mathrm{W} \pm 58.53^{\circ}$ in the positive phase and $130.94^{\circ} \mathrm{W} \pm 66.20^{\circ}$ when the SAM is negative, with the difference not being statistically significant. As the name implies, the SAM is primarily an annular mode of variability so the limited zonal displacement of the ASL throughout the different phases is not surprising. The climatology indicates that the ASL is slightly further west (east) during the La Nina (El Nino) phase of ENSO, but the difference is not statistically significant. This is somewhat surprising as there is more blocked conditions over the ABS during the El Niño phase. However, the variability in the longitude of the low is large.

\section{Trends in the ASL over the last 30 years}

Over the period 1979 - 2008 the depth of the ASL has experienced a complex picture of change over the year (Figures 12 and 13). The low has deepened by $1.7 \mathrm{hPa} \mathrm{dec}^{-1}$ in January (significant at $<10 \%$ level) and by a smaller amount in February. During both these months 
the SAM has become more positive and in January the MSLP has decreased around the whole of the circumpolar trough, but the decrease has been greatest in the area of the ASL, over the western Weddell Sea and near the Amery embayment. This deepening of the low in January is consistent with the warming in Faraday of $0.2^{\circ} \mathrm{C} \mathrm{dec}^{-1}$ (http://www.antarctica.ac.uk/met/gima/), the decrease in sea ice over the Bellingshausen Sea (Stammerjohn et al., 2008) and the greater snow accumulation on the western side of the Peninsula (Thomas et al., 2008).

The ASL has deepened most during September with a decrease of central pressure of $-2.1 \mathrm{hPa} \mathrm{dec}{ }^{-1}$ (significant at $<10 \%$ level). However, much of this trend is the result of the remarkably deep ASL that occurred in September 2008, when it had a central pressure of $958 \mathrm{hPa}$, which is the lowest mean monthly pressure in the 30 year record. If this month is excluded the depth of the low over $1979-2008$ decreased by $-1.2 \mathrm{hPa} \mathrm{dec}{ }^{-1}$, which is not significant. Figure 12 suggests a broadly semi-annual change in the depth of the low, with decreases in central pressure in the spring and autumn, although displaced by one month from the absolute minimum in pressure shown in Figure 3, and increasing pressure in the winter. Calculation of the second harmonic of the annual pressure cycle in this sector of the Antarctic coastal region does indeed indicate a slight increase in amplitude of the SAO.

March was a month of marked change in the ASL with an increase in central pressure (significant at $<10 \%$ level), a shift to the east of more than $7^{\circ} \mathrm{dec}^{-1}$ and a shift to a more northerly location of $1.4^{\circ} \mathrm{dec}^{-1}$ (significant at the $1 \%$ level). Examination of the MSLP fields indicates this took place as surface pressures increased in the circumpolar trough, with corresponding falls around this sector near $50^{\circ} \mathrm{S}$. At upper levels the $300 \mathrm{hPa}$ winds increased on the northern edge of the polar front jet and there was a corresponding decrease in strength of the sub-tropical jet (both significant at $<5 \%$ level). The strength of these two jets exhibits an out of phase relationship during the ENSO cycle with a strengthening (weakening) of the polar (sub-tropical) front jet during the La Niña (El Niño) phase when SSTs across the central Pacific Ocean are colder (warmer) (Chen et al., 1996). Over 19792008 SSTs across the central Pacific have decreased (although only small areas had changes that were significant at $<5 \%$ level) suggesting that the changes in the ASL during this month are associated with broad scale changes across the Pacific. However, while the changes during this month exhibit some of the characteristic alterations to the ASL seen during La Niña events, the increase in pressure is unlike that of the La Niña phase. The teleconnection between the tropical Pacific and the Antarctic is rather weak in March and the ASL is affected at this time of year by both tropical and high latitude forcing factors. 
April is the month when the ASL has experienced its greatest trend in southward displacement of $1.0^{\circ} \mathrm{dec}^{-1}$, which is significant at the $<5 \%$ level. As discussed earlier, the meridional location of the low is strongly influenced by the phase of the SAM and April is the month when the SAM has experienced its greatest shift to more positive values $\left(0.76 \mathrm{dec}^{-}\right.$ ${ }^{1}$ ) according to the Marshall index (Marshall, 2003). However, other factors than the SAM influence the meridional location of the ASL and the correlation of the SAM index and the meridional location of the low over the year is only -0.31 (a more southerly ASL with positive SAM). This is highlighted by the fact that in May the SAM has its second largest positive trend, yet the ASL is located slightly further north.

During May the depth of the ASL has decreased by more than $1 \mathrm{hPa} \mathrm{dec}{ }^{-1}$ and the low has experienced the greatest eastward shift for any month of the year, although because of the large inter-annual variability in the zonal location of the low the trend is not significant. The trend in the MSLP indicates a large drop in pressure along the Antarctic coast and over the circumpolar trough to the Ross Sea. Based on model experiments Turner et al. (2009) suggested that the drop in MSLP at this time of year was a result of the loss of stratospheric ozone. Although the 'ozone hole' is a phenomenon of the Austral spring, the resultant changes in atmospheric circulation descent over the subsequent months and give a decrease in depth of the ASL in May.

November is the month that has experienced the largest westward movement of the ASL, although at this time of year there has been only a small change in MSLP and meridional location. The change has occurred because of a couplet of changes in MSLP, with values increasing over the Bellingshausen Sea and decreasing over the Ross Sea. This has taken place as the phase of wave numbers 2 and 3 have shifted westwards by about 10-15 degrees.

\section{Discussion and conclusions}

The ASL is the dominant synoptic-scale climatological feature of the region between the Antarctic Peninsula and the Ross Ice Shelf and variability in its depth and location has a major influence on the atmospheric circulation, temperature and precipitation across West Antarctica and this sector of the Southern Ocean. Previous work has suggested that changes in the ASL have been responsible for significant trends in temperature and precipitation across West Antarctica, although some of the studies gave conflicting results as they were based on different periods and identified the ASL in different ways. Using the high quality 
meteorological analyses available for the last 30 years we have been able to create a consistent climatology of the low.

The teleconnection between the tropical Pacific and the Antarctic coastal regions is weak in the summer but strengthens towards winter as the polar vortex develops. Our results are in general agreement with those of Bertler et al. (2004), with the 30 year climatology suggesting that the ASL is deeper (weaker) and located further west (east) during the La Niña (E1 Niño) phase of ENSO, although the difference in the zonal location of the ASL between the different phases of ENSO is not statistically significant. However, tropical Pacific climate variability is not described fully by the various indices of ENSO alone. For example, Ding et al. (2011) have recently suggested that the warming of West Antarctica that has taken place over the last 50 years (Steig et al., 2009) is a result of an increase in tropical Pacific SSTs that is unrelated to ENSO. The changes we find in the ASL during March reflect this mix of ENSO-related broadscale circulation changes across the South Pacific and other factors influencing the depth of the ASL.

Previous studies, and the work presented here, suggest that both tropical forcing via a teleconnection to the high latitude Pacific and a SAM-like variability play a part in changes to the ASL. The SAM has become more positive over the last 30 years, largely as a result of the loss of stratospheric ozone (Arblaster and Meehl, 2006). Although the loss of ozone is largest during the spring, the greatest impact on the surface circulation is during the summer and autumn. However, this does not translate into a simple deepening of the ASL during these two seasons. In January, MSLP has decreased all around the circumpolar trough, and especially in the region of the ASL so that the central pressure of the low has decreased. This has been re-enforced by an increase in the amplitude of wave number 3 during this month. February has seen a small decrease in MSLP around the continent, but the amplitude of wave number 3 has decreased resulting in little change in the depth of the ASL. In March the amplitude of wave number 3 has increased, but the broadscale alterations to the jet structure across the South Pacific discussed earlier have resulted in pressure increases across the Amundsen Sea and a tendency for the low to fill. In May the trends in MSLP around most of the circumpolar trough have been small except for a marked deepening in the vicinity of the ASL.

The markedly different monthly trends in MSLP around the continent and the evidence for influences of both high and low latitude forcing factors complicates the interpretation of recent changes in the ASL. They also make it very difficult to reconstruct the location and depth of the ASL from the ice core record. The in-situ meteorological observations from the 
stations on the Antarctic Peninsula, as well as ice core records, suggest long term changes in the atmospheric circulation and sea ice extent over the ABS. The high quality meteorological analyses we have for the last 30 years provide data with which to calibrate the ice core data and offer the potential to extend our knowledge of atmospheric circulation variability back into the pre-1979 period. However, the trends in the depth and location of the ASL since 1979 suggest variability between seasons and even between months, which may make the investigation of atmospheric circulation using the ice core record difficult. Much of the work on ice core data has been concerned with examining annual records as it is easiest to differentiate summer and winter signals. In some high accumulation areas it is possible to resolve seasonal signals, but the confidence in obtaining clear markers of the individual seasons is much lower than for the annual data. The complexity in the variability and change in the ASL as revealed from the reanalysis and operational fields suggests that resolving changes in the ASL before 1979 may present a number of challenges. 
Figures
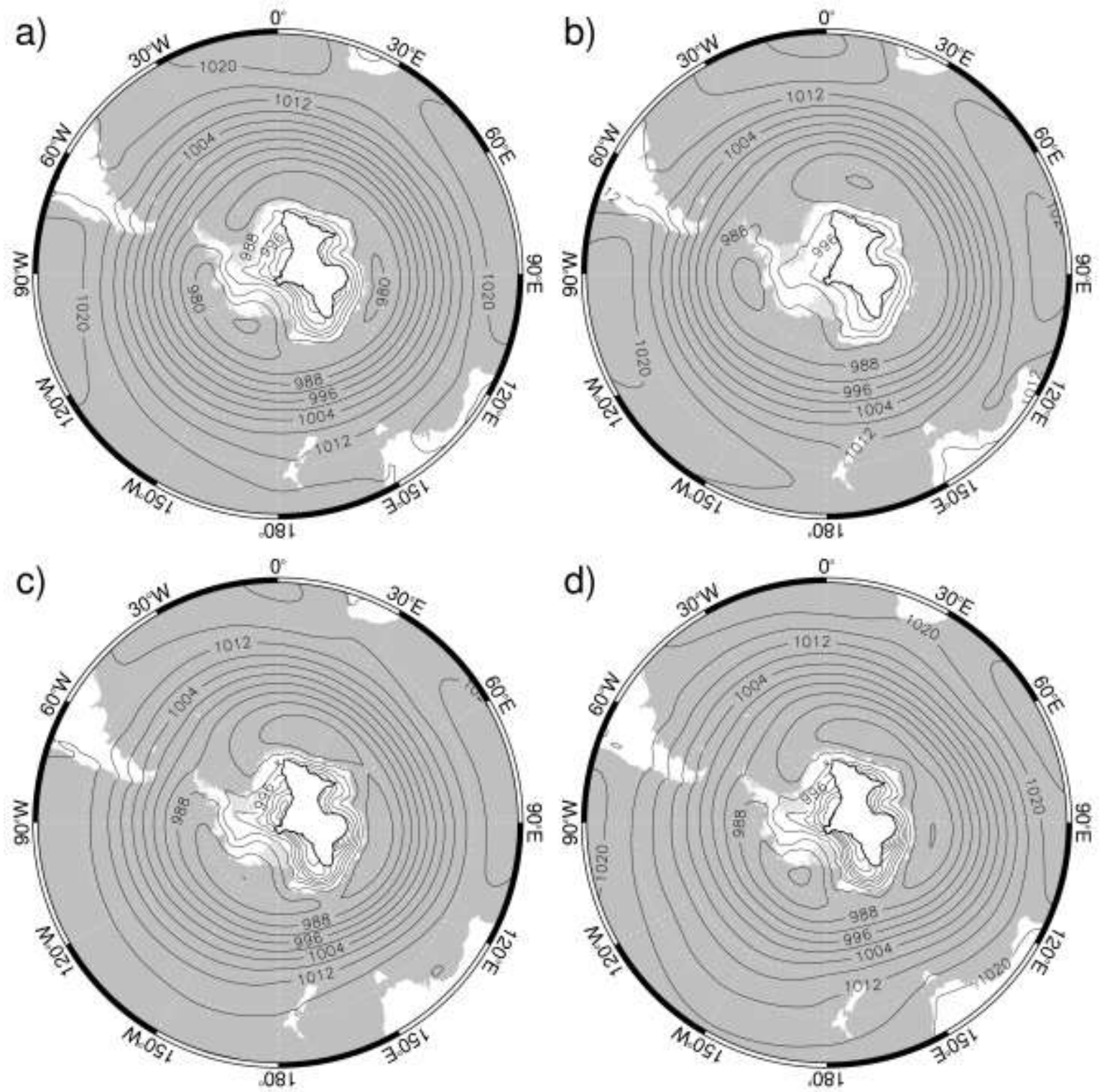

Figure 1 Mean MSLP for 1979-2008 from ERA-40 and ECMWF operational analyses. A) Spring, b) summer, c) autumn and d) winter. 


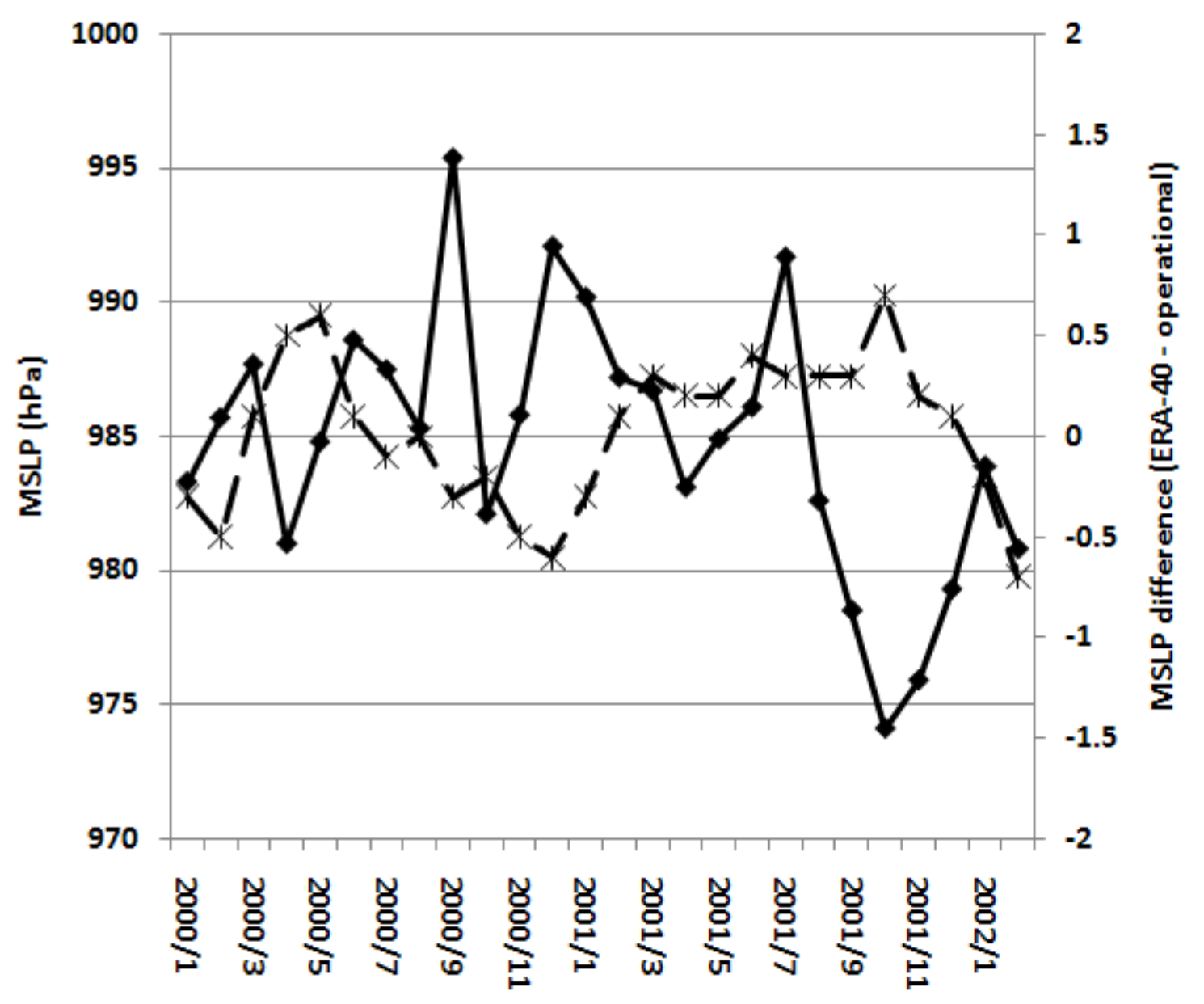

Figure 2. The monthly mean MSLP for the area $60-75^{\circ} \mathrm{S}, 50-180^{\circ} \mathrm{W}$ from the ERA-40 data set over the period January 2000 to February 2002 (solid line) and the difference between the ERA and operational analyses (broken line). 


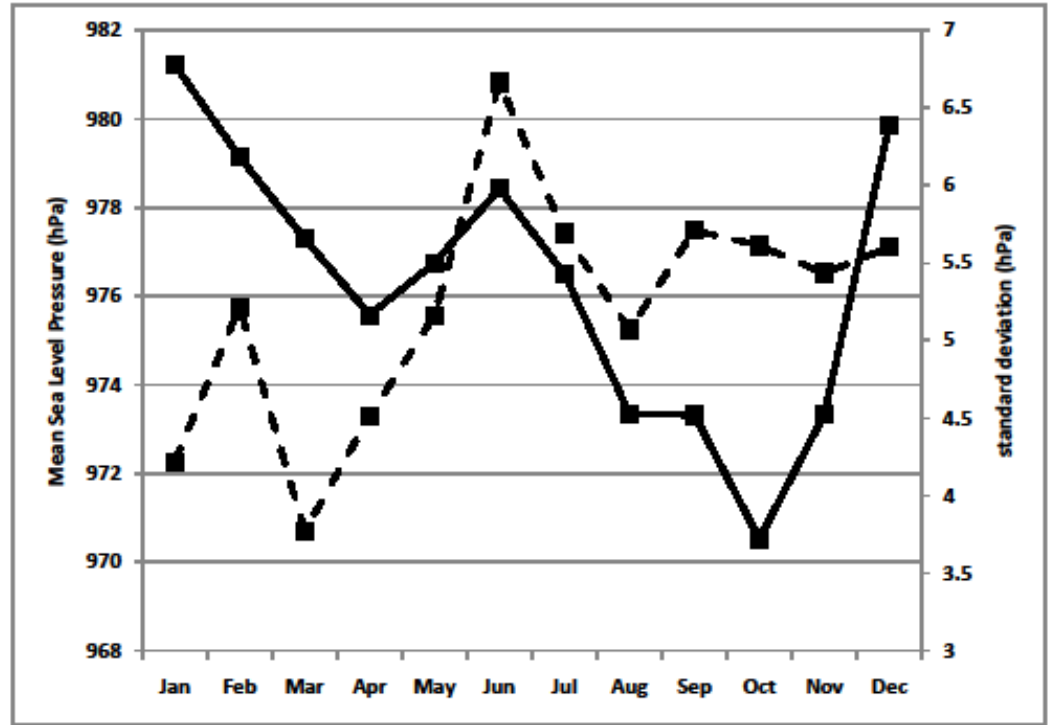

Figure 3. The mean depth (hPa) (solid line) and sd (hPa) (broken line) of the ASL over 1979 -2008 . 


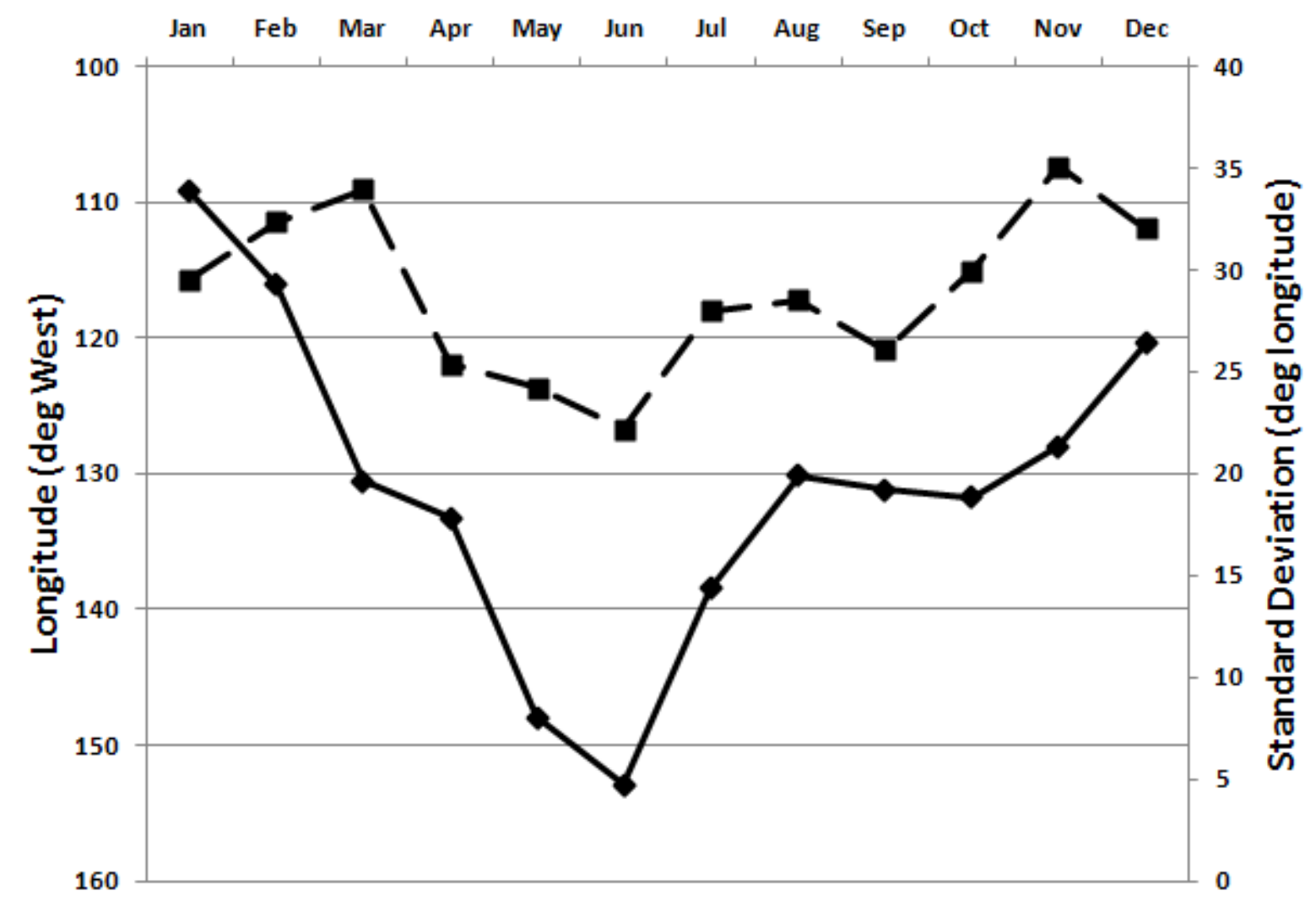

(a) 


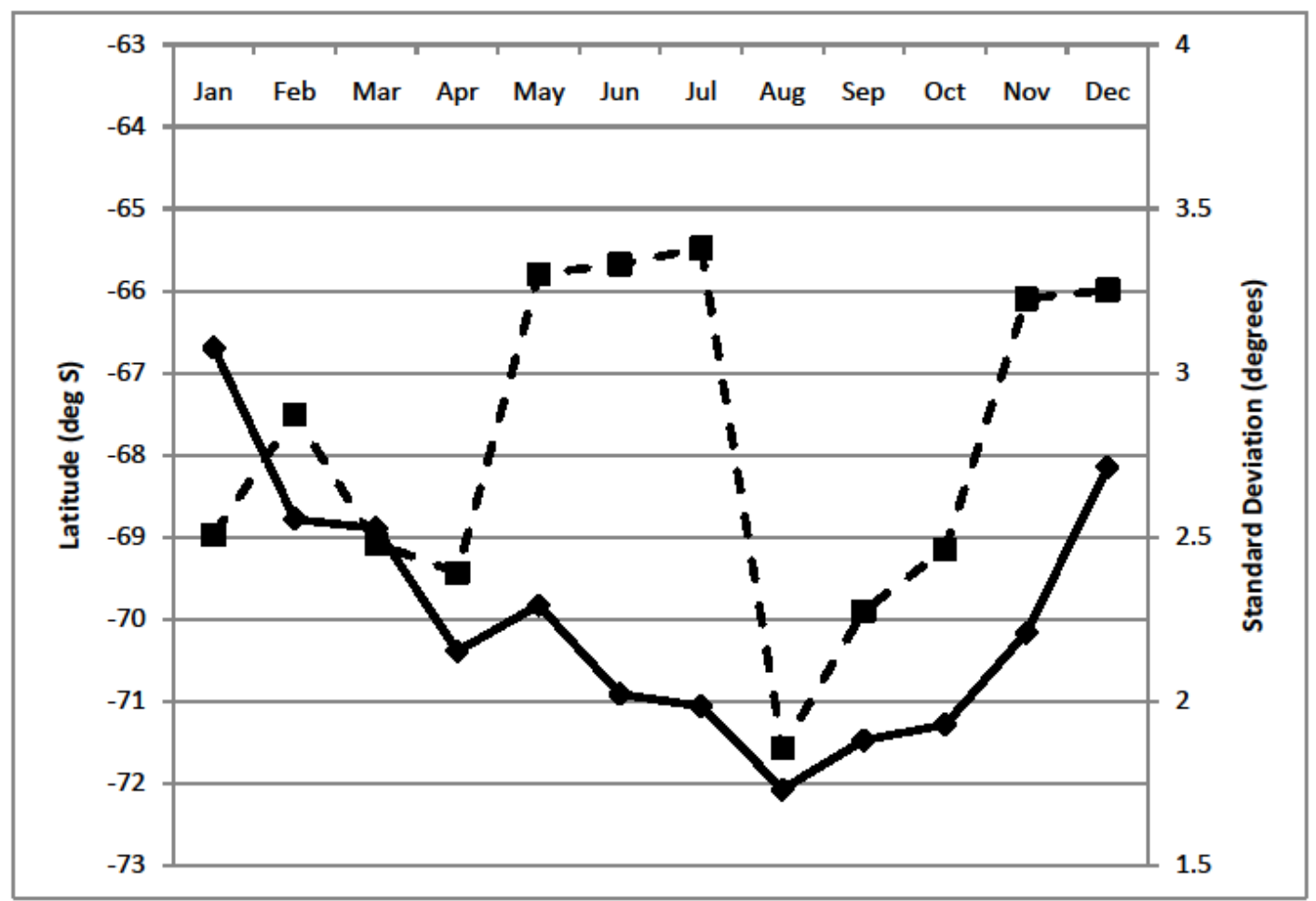

(b)

Figure 4. The annual cycle of the (a) longitude and (b) latitude of the ASL over 1979 - 2008 (solid lines). The sd of the data is also shown on both figures (broken lines). 


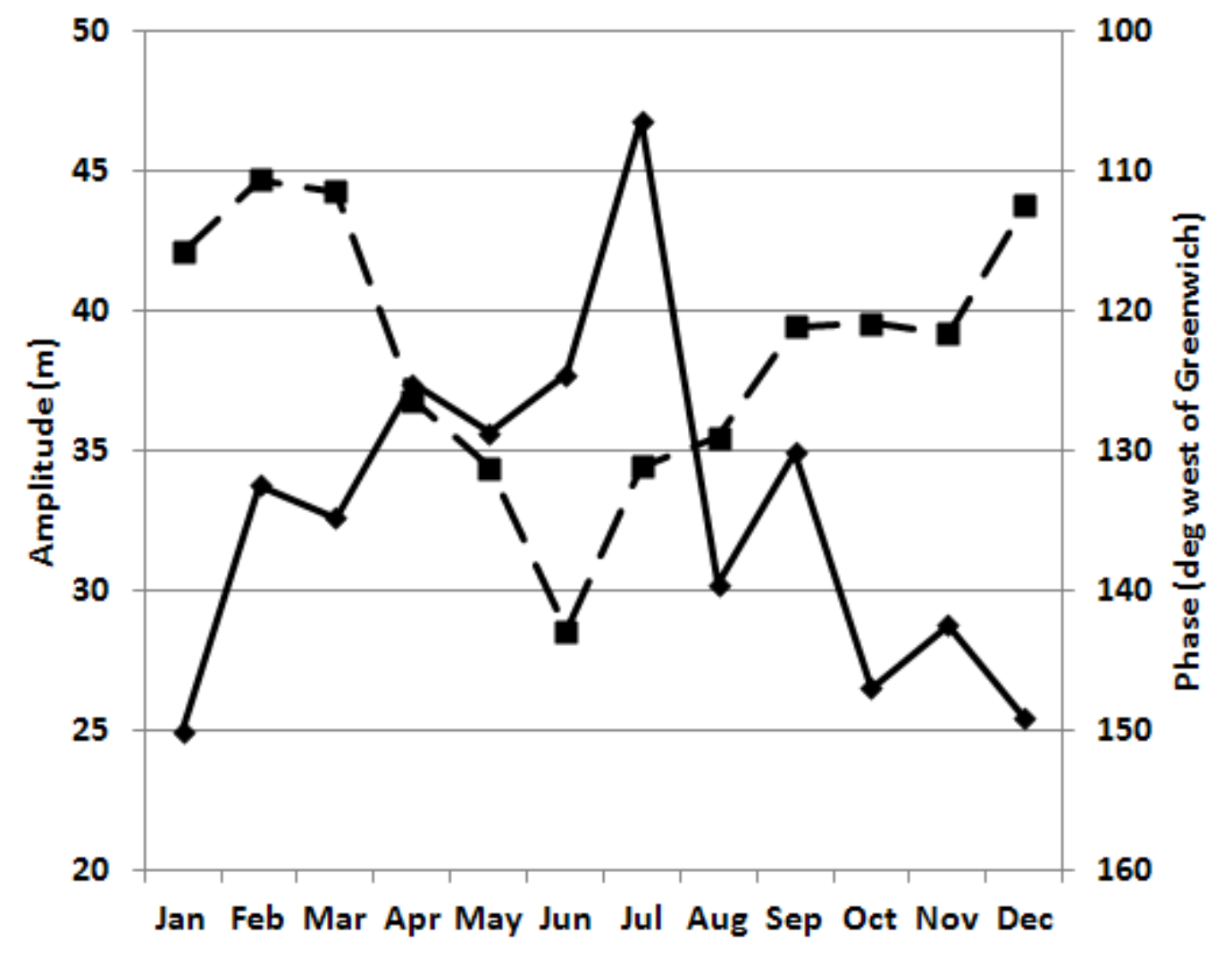

Figure 5. The mean amplitude (m) (solid line) and phase (degrees west of Greenwich of the trough between the Antarctic Peninsula and the Ross Sea) (broken line) of the $500 \mathrm{hPa}$ wave number 3 at $65^{\circ} \mathrm{S}$ over $1979-2008$. 


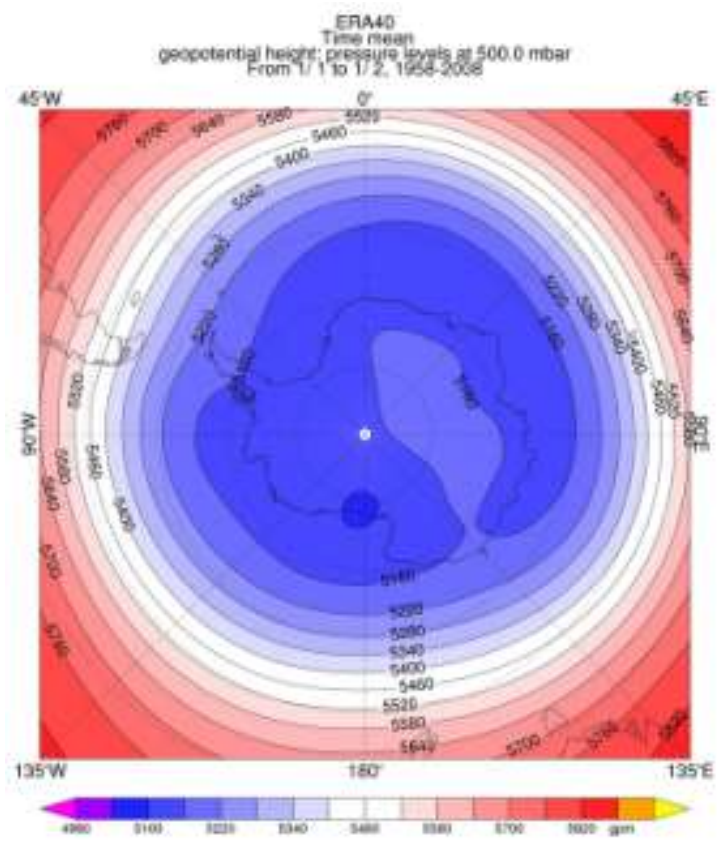

(a)

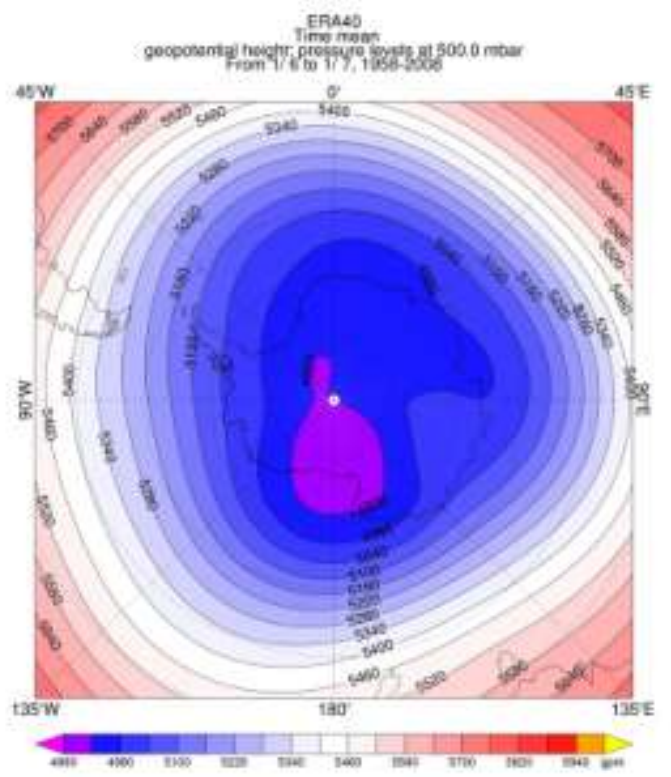

(b)

Figure 6. The mean (1979-2008) $500 \mathrm{hPa}$ height field (m) for (a) January and (b) June. 

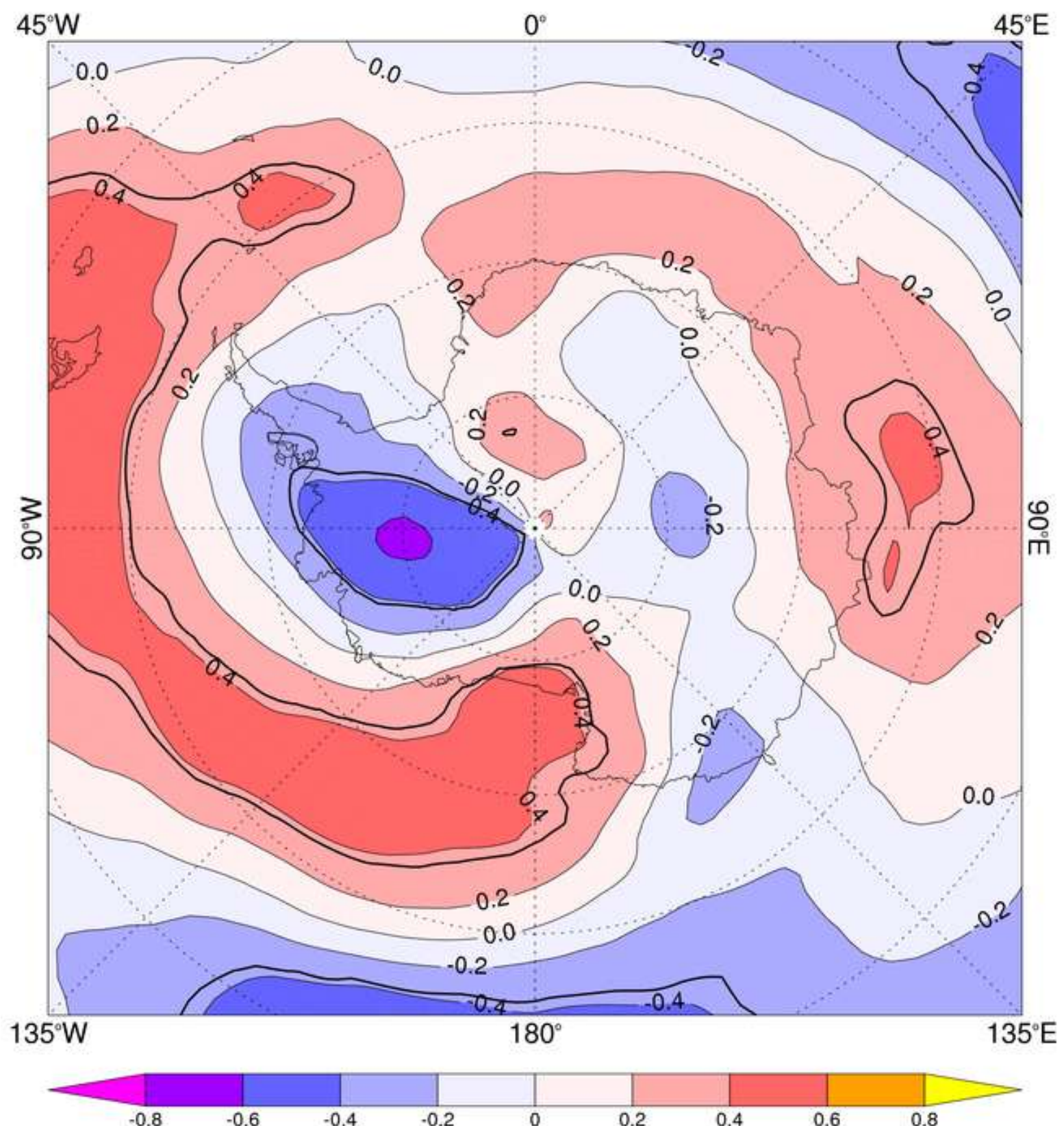

Figure 7a. The correlation of the longitude of the ASL in winter with (a) the zonal and (b) the meridional components of the winter $500 \mathrm{hPa}$ wind speed. Areas where the correlations are significant at $<5 \%$ level are enclosed by bold lines. 


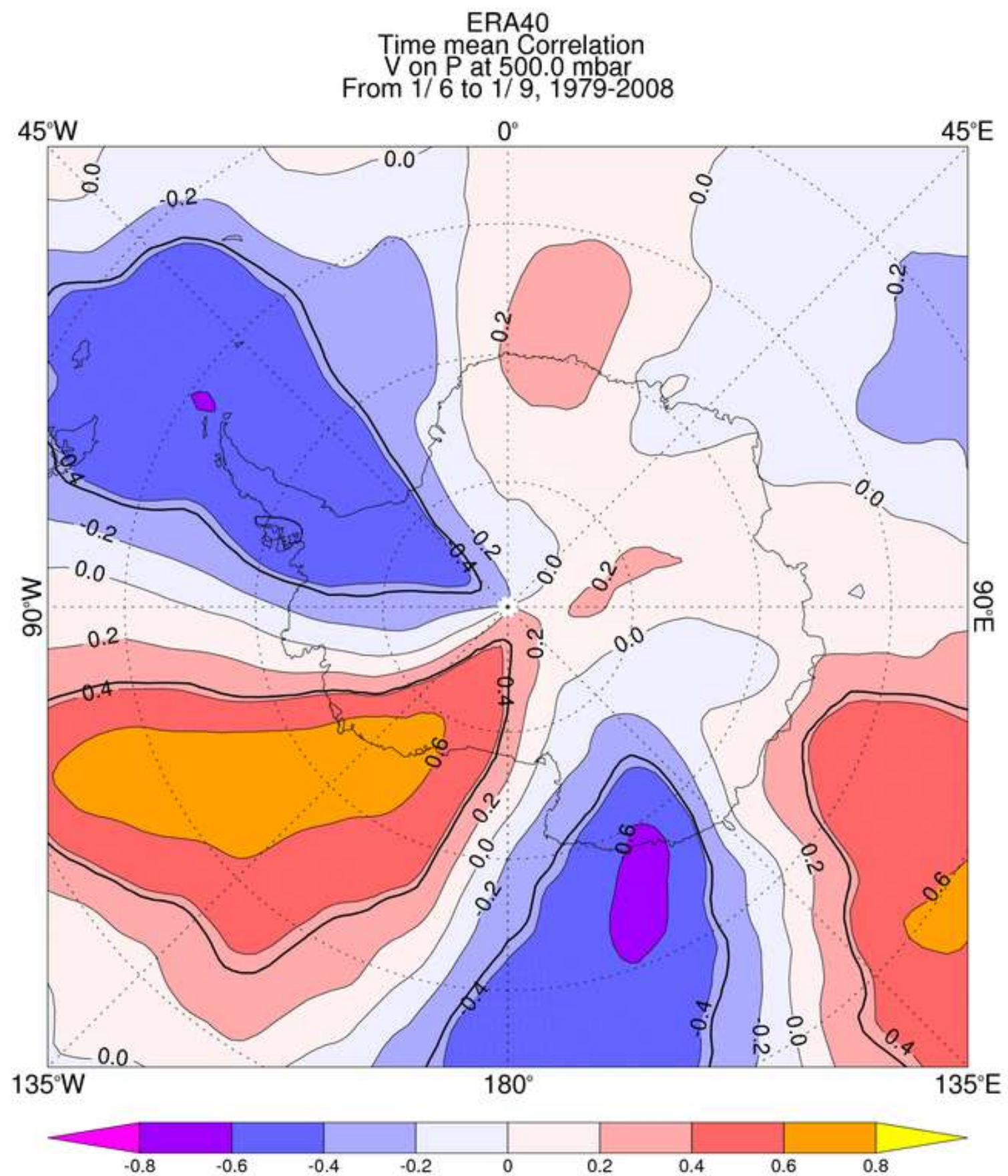

Figure $7 b$. 


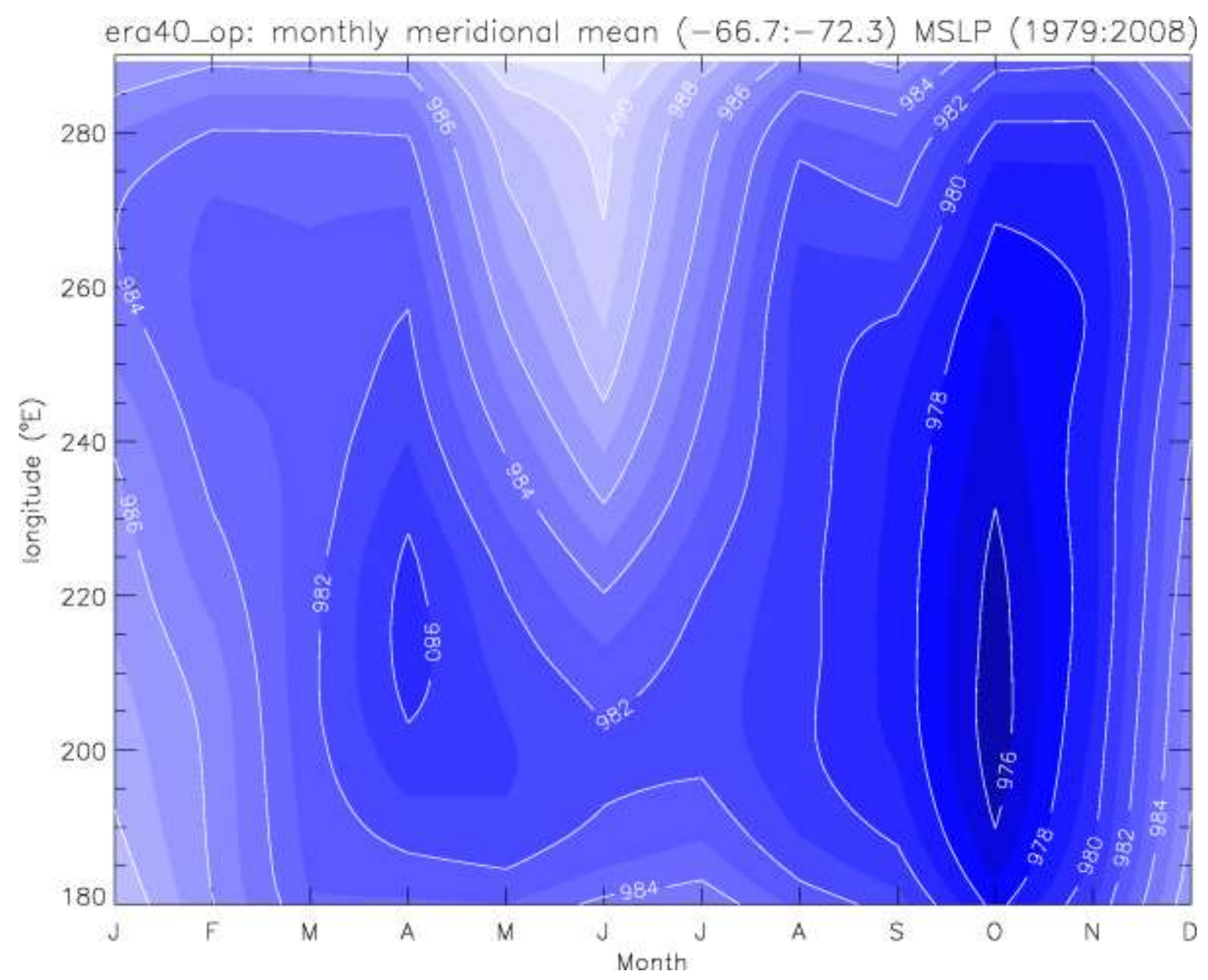

Figure 8. The annual cycle of MSLP between $290^{\circ}$ and $180^{\circ} \mathrm{E}$ and averaged over $66.7^{\circ}-$ $72.3^{\circ} \mathrm{S}$. 


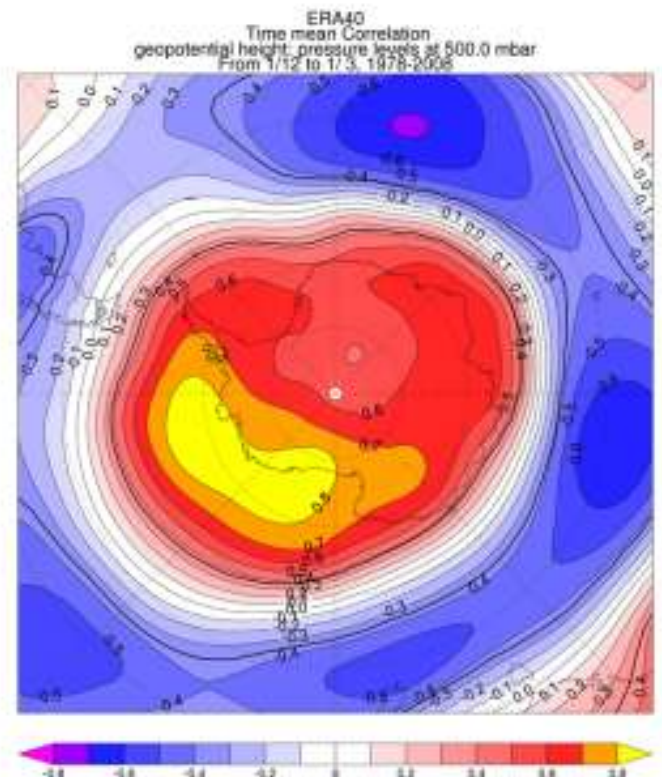

Figure 9a. Summer

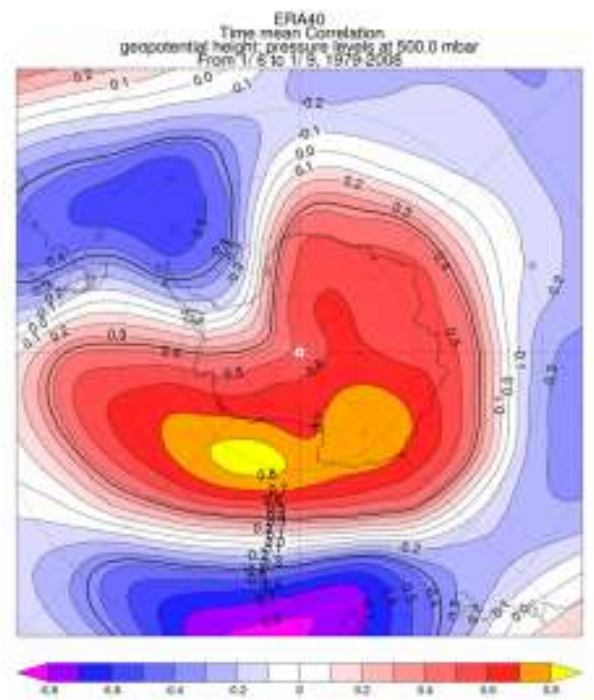

Figure 9b. Winter

Figure 9. The correlation of the depth of the ASL with $500 \mathrm{hPa}$ heights across high and midlatitude areas of the Southern Hemisphere over 1979-2008. (a) Summer and (b) Winter. Areas where the correlations are significant at the 5\% level are bounded by the bold line. 


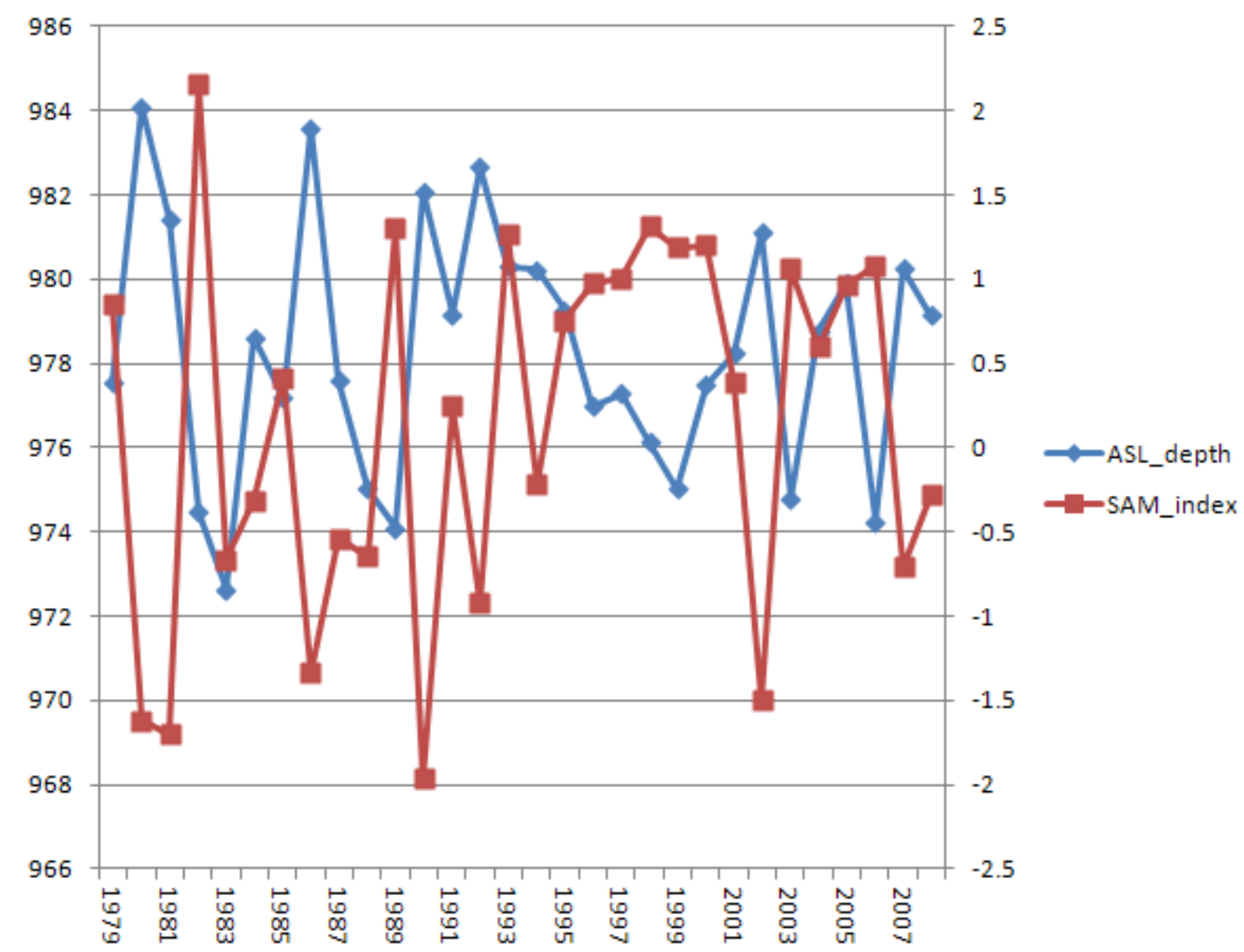

Figure 10. The depth of the ASL in Autumn and the SAM index during that season. 


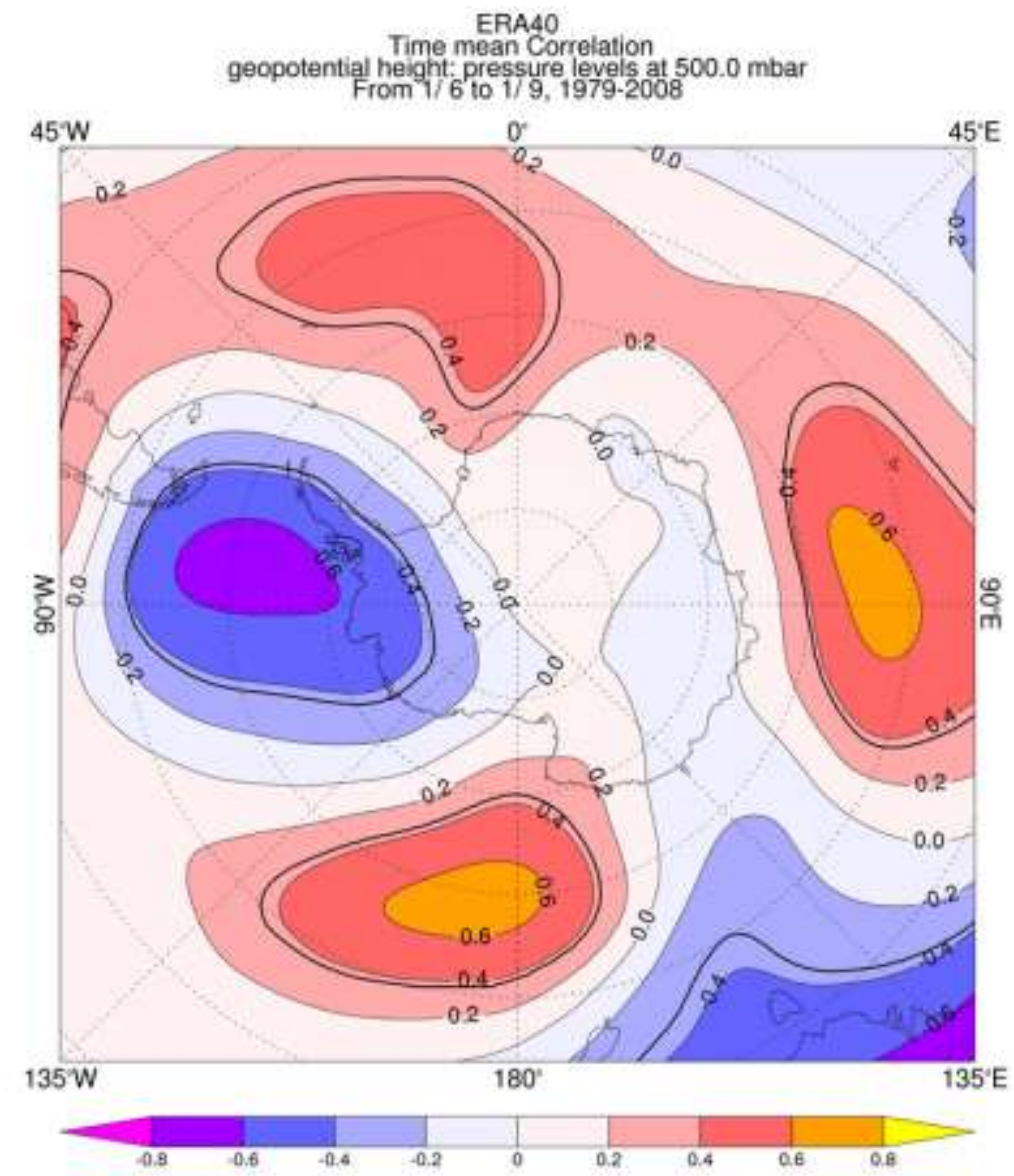

Figure 11. Correlation of the longitude of the ASL in winter and $500 \mathrm{hPa}$ heights. The bold line encloses areas where the correlation is significant at $<5 \%$ level. 


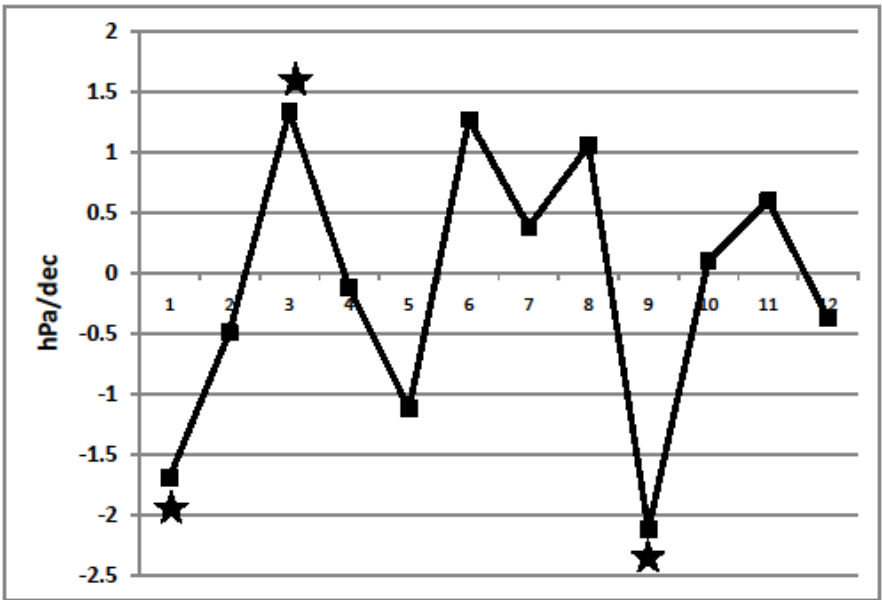

Figure 12. The trend in the depth of the ASL over $1979-2008(\mathrm{hPa} / \mathrm{dec})$. The months marked with a star had trends that were significant at less than the $10 \%$ level. 


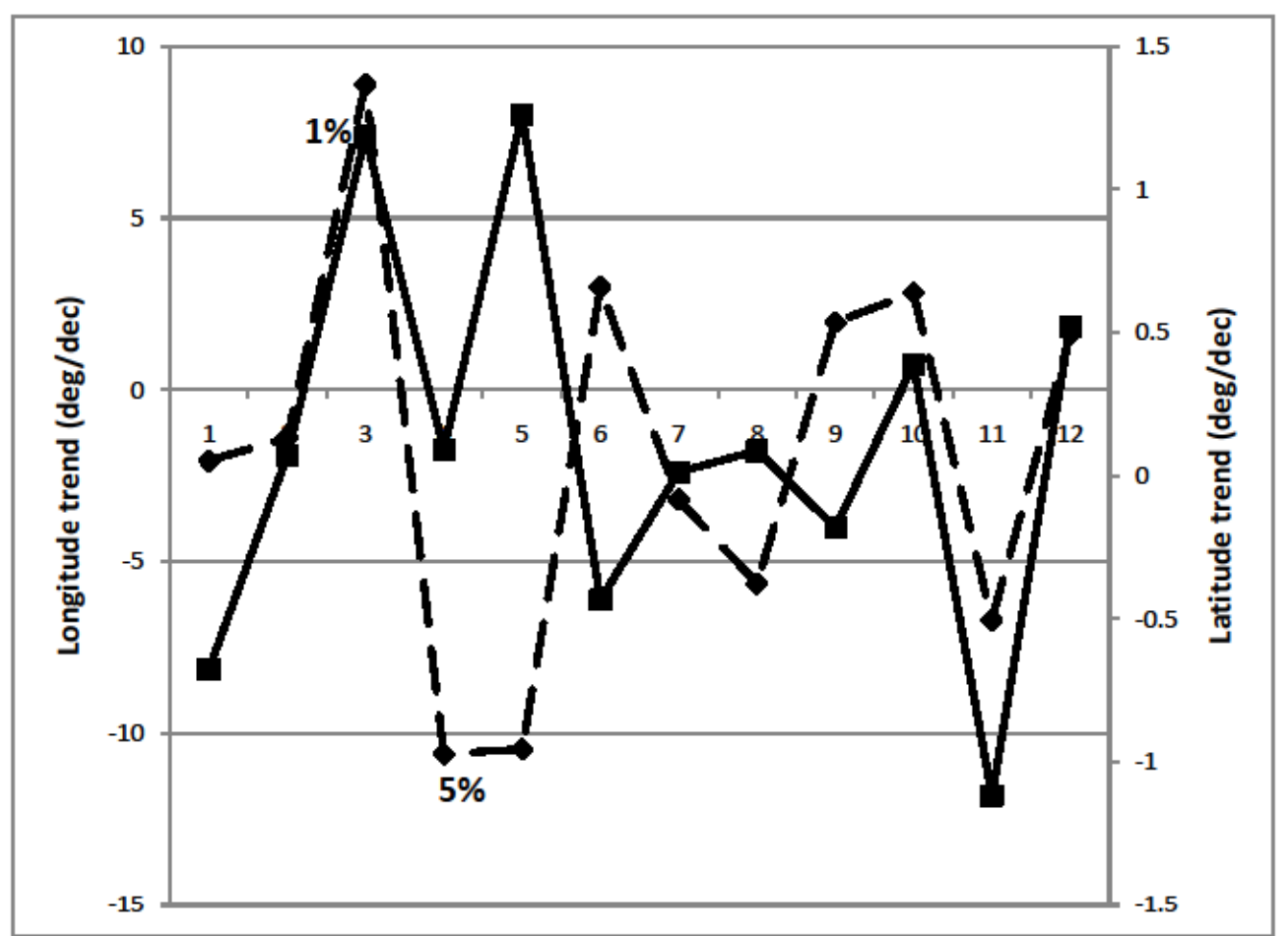

Figure 13. The trends in the latitude (broken line) and longitude (solid line) of the ASL over $1979-2008$ (degrees/dec). The percentage figures indicate the statistical significance of the trends in latitude. 


\section{REFERENCES}

Arblaster, J. and Meehl, G. A. 2006. Contributions of external forcings to Southern Annular Mode trends. Journal of Climate 19: 2896-2905.

Baines, P. G. and Fraedrich, K. 1989. Topographic effects on the mean tropospheric flow patterns around Antarctica. Journal of the Atmospheric Sciences 46: 3401-3415.

Bertler, N. A. N., Barrett, P. J., Mayewski, P. A., Fogt, R. L., Kreutz, K. J. and Shulmeister, J. 2004. El Niño suppresses Antarctic warming. Geophysics Research Letters 31: L15207, doi:10.1029/2004GL020749.

Chen, B., Smith, S. R. and Bromwich, D. H. 1996. Evolution of the tropospheric split jet over the South Pacific Ocean during the 1986-89 ENCO cycle. Monthly Weather Review 124: 1711-1731.

Cullather, R. I., Bromwich, D. H. and Van Woert, M. L. 1996. Interannual variations in Antarctic precipitation related to E1 Nino southern oscillation. Journal of Geophysical Research 101: 19109-19118.

Ding, Q., Steig, E. J., Battisti, D. S. and Kuttel, M. 2011. Winter warming in West Antarctica caused by central tropical Pacific warming. Nature Geoscience : DOI:10.1038/NGEO1129.

Doran, P. T., Priscu, J. C., Lyons, W. B., Walsh, J. E., Fountain, A. G., McKnight, D. M., Moorhead, D. L., Virginia, R. A., Wall, D. H., Clow, G. D., Fritsen, C. H., McKay, C. P. and Parsons, A. N. 2002. Antarctic climate cooling and terrestrial ecosystem response. Nature 415: 517-520.

Fogt, R. L. and Bromwich, D. H. 2006. Decadal variability of the ENSO teleconnection to the high latitude South Pacific governed by coupling with the Southern Annular Mode. Journal of Climate 19: 979-997.

Fogt, R. L., Bromwich, D. H. and Hines, K. M. 2011. Understanding the SAM influence on the South Pacific ENSO teleconnection. Climate Dynamics 36 [7-8]: 1555-1576.

Fogt, R. L., Wovrosh, A. J., Langen, R. A. and Simmonds, I. 2012. The characteristic variability and connection to the underlying synoptic activity of the AmundsenBellingshausen Seas Low. Journal of Geophysical Research 117: D07111, doi:10.1029/2011JD017337.

Genthon, C., Krinner, G. and Sacchettini, M. 2003. Interannual Antarctic tropospheric circulation and precipitation variability. Climate Dynamics 21: 289-307.

Hall, A. and Visbeck, M. 2002. Synchronous variability in the Southern Hemisphere atmosphere, sea ice, and ocean resulting from the annular mode. Journal of Climate 15: 3043-3057.

Hines, K. M., Bromwich, D. H. and Marshall, G. J. 2000. Artificial surface pressure trends in the NCEP/NCAR reanalysis over the Southern Ocean and Antarctica. Journal of Climate 12: 3940-3952.

Hobbs, W. R. and Raphael, M. N. 2007. A representative time-series for the Southern Hemisphere zonal wave 1. Geophysical Research Letters 34 [5].

Karoly, D. J. 1989. Southern Hemisphere circulation features associated with El NiñoSouthern Oscillation events. Journal of Climate 2: 1239-1252.

King, J. C. 2003. Validation of ECMWF sea level pressure analyses over the Bellingshausen Sea, Antarctica. Weather and Forecasting 18: 536-540.

King, J. C. and Harangozo, S. A. 1998. Climate change in the western Antarctic Peninsula since 1945: observations and possible causes. Annals of Glaciology 27: 571-575. 
Kreutz, K. J., Mayewski, P. A., Pittalwala, I. I., Meeker, L. D., Twickler, M. S. and Whitlow, S. I. 2000a. Sea level pressure variability in the Amundsen Sea region inferred from a West Antarctic glaciochemical record. Journal of Geophysical Research 105 [D3]: 4047-4059.

Kreutz, K. J., Mayewski, P. A., Meeker, L. D., Twickler, M. S. and Whitlow, S. I. 2000b. The effect od spacial and temporal accumulation rate variability in West Antarctica on soluble ion deposition. Geophysics Research Letters 27: 2517-2520.

Lachlan-Cope, T. A. and Connolley, W. M. 2006. Teleconnections between the tropical Pacific and the Amundsen-Bellingshausen Sea: role of the El Niño/Southern Oscillation. Journal of Geophysical Research 111 [D23]: doi:10.1029/2005JD006386.

Lachlan-Cope, T. A., Connolley, W. M. and Turner, J. 2001. The role of the nonaxisymmetric Antarctic orography in forcing the observed pattern of variability of the Antarctic climate. Geophysics Research Letters 28 [21]: 4111-4114.

Le Quére, C., Raupach, M. R., Canadell, J. G., Marland, G., Bopp, L., Ciais, P., Conway, T. J., Doney, S. C., Feely, R. A., Foster, P., Friedlingstein, P., Gurney, K., Houghton, R. A., House, J. I., Huntingford, C., Levy, P. E., Lomas, M. R., Majkut, J., Metzl, N., Ometto, J. P., Peters, G. P., Prentice, I. C., Randerson, J. T., Running, S. W., Sarmiento, J. L., Schuster, U., Sitch, S., Takahashi, T., Viovy, N., van der Werf, G. R. and Woodward, F. I. 2009. Trends in the sources and sinks of carbon dioxide. Nature Geoscience 2 [12]: 831-836.

Limpasuvan, V. and Hartmann, D. L. 1999. Eddies and the annular modes of climate variability. Geophysics Research Letters 26: 3133-3136.

Marshall, G. J. 2003. Trends in the Southern Annular Mode from observations and reanalyses. Journal of Climate 16: 4134-4143.

Marshall, G. J., Orr, A., van Lipzig, N. P. M. and King, J. C. 2006. The impact of a changing Southern Hemisphere Annular Mode on Antarctic Peninsula summer temperatures. Journal of Climate 19 [20]: 5388-5404.

Raphael, M. N. 2004. A zonal wave 3 index for the Southern Hemisphere. Geophysics Research Letters 31: L23212, doi:10.1029/2004GL020365.

Schneider, D. P., Deser, C. and Okumura, Y. 2012. An assessment and interpretation of the observed warming of West Antarctica in the austral spring. Climate Dynamics 38 [12]: 323-347.

Schneider, D. P., Steig, E. J. and Comiso, J. C. 2004. Recent climate variability in Antarctica from satellite-derived temperature data. Journal of Climate 17: 1569-1583.

Stammerjohn, S., Martinson, D. G., Smith, R. C., Yuan, X. and Rind, D. 2008. Trends in Antarctic annual sea ice retreat and advance and their relation to El Niño-Southern Oscillation and Southern Annular Mode variability. Journal of Geophysical Research 113: doi: $10.1029 / 2007 J C 004269$.

Steig, E. J., Schneider, D. P., Rutherford, S. D., Mann, M. E., Comiso, J. C. and Shindell, D. T. 2009. Warming of the Antarctic ice-sheet surface since the 1957 International Geophysical Year. Nature 457: 459-462.

Tamura, T., Ohshima, K. I. and Nihashi, S. 2008. Mapping of sea ice production for Antarctic coastal polynyas. Geophysics Research Letters 35 [7].

Thomas, E. R., Marshall, G. J. and McConnell, J. R. 2008. A doubling in snow accumulation in the western Antarctic Peninsula since 1850. Geophysics Research Letters 35: L01706, doi:10.1029/2007GL032529.

Thompson, D. W. J. and Solomon, S. 2002. Interpretation of recent Southern Hemisphere climate change. Science 296: 895-899.

Turner, J. 2004. The El Niño-Southern Oscillation and Antarctica. International Journal of Climatology 24: 1-31. 
Turner, J., Colwell, S. R. and Harangozo, S. A. 1997. Variability of precipitation over the coastal western Antarctic Peninsula from synoptic observations. Journal of Geophysical Research 102: 13999-14007.

Turner, J., Colwell, S. R., Marshall, G. J., Lachlan-Cope, T. A., Carleton, A. M., Jones, P. D., Lagun, V., Reid, P. A. and Iagovkina, S. 2005. Antarctic climate change during the last 50 years. International Journal of Climatology 25: 279-294.

Turner, J., Comiso, J. C., Marshall, G. J., Lachlan-Cope, T. A., Bracegirdle, T. J., Maksym, T., Meredith, M. P., Wang, Z. and Orr, A. 2009. Non-annular atmospheric circulation change induced by stratospheric ozone depletion and its role in the recent increase of Antarctic sea ice extent. Geophysics Research Letters 36: L08502, doi:10.1029/2009GL037524.

Uppala, S. M., Kallberg, P. W., Simmons, A. J., Andrae, U., Bechtold, V. D., Fiorino, M., Gibson, J. K., Haseler, J., Hernandez, A., Kelly, G. A., Li, X., Onogi, K., Saarinen, S., Sokka, N., Allan, R. P., Andersson, E., Arpe, K., Balmaseda, M. A., Beljaars, A. C. M., Van de Berg, L., Bidlot, J., Bormann, N., Caires, S., Chevallier, F., Dethof, A., Dragosavac, M., Fisher, M., Fuentes, M., Hagemann, S., Holm, E., Hoskins, B. J., Isaksen, L., Janssen, P. A. E. M., Jenne, R., McNally, A. P., Mahfouf, J. F., Morcrette, J. J., Rayner, N. A., Saunders, R. W., Simon, P., Sterl, A., Trenberth, K. E., Untch, A., Vasiljevic, D., Viterbo, P. and Woollen, J. 2005. The ERA-40 re-analysis. Quarterly Journal of the Royal Meteorological Society 131 [612]: 2961-3012.

Vaughan, D. G., Bamber, J. L., Giovinetto, M., Russell, J. and Cooper, A. P. R. 1999. Reassessment of net surface mass balance in Antarctica. Journal of Climate 12: 933 946.

Yuan, X. 2004. ENSO-related impacts on Antarctic sea ice: A synthesis of phenomenon and mechanisms. Antarctic Science 16: 415-425.

Yuan, X. and Martinson, D. G. 2001. The Antarctic dipole and its predictability. Geophysics Research Letters 28 [18]: 3609-3612. 